\title{
Factors Affecting Service Share Prices at Amman Stock Exchange
}

\author{
Abdul Aziz Farid Saymeh ${ }^{1} \&$ Rashed Mohamad Salameh ${ }^{2}$ \\ ${ }^{1}$ Associate Professor in Finance, Accounting and Financial Sciences Department, Middle East University, \\ Amman, Postal Code 11831, Jordan \\ 2 Associate Professor in Finance, Head of Accounting and Financial Sciences Department, Middle East \\ University, Amman, Postal Code 11831, Jordan \\ Correspondence: Abdul Aziz Farid Saymeh, Associate Professor in Finance, Accounting and Financial Sciences \\ Department, Middle East University, Amman, Postal Code 11831, Jordan. E-mail: \\ rawad_abdulaziz@outlook.com
}

Received: April 2, 2019

doi:10.5539/ijbm.v14n7p149
Accepted: April 25, 2019

Online Published: June 15, 2019

URL: https://doi.org/10.5539/ijbm.v14n7p149

\begin{abstract}
The research objective was to identify the determinants of services stock prices. Research community was represented by the service companies listed in Jordan's Amman Stock Exchange (ASE). The companies were selected to whose shares continued trading during the study period (2010-2015). The study sample was composed of (27) shareholding companies which were listed on the Amman Stock Exchange (ASE) during the afore mentioned period.

The study results revealed that there was a significant impact of the factors selected such as: profits (distributed profits, return on assets and net cash flows from operations) on the market value of service companies share prices listed on ASE.

The study recommended that further studies ought to be conducted to specify the factors that might affect the market value of listed companies' shares.
\end{abstract}

Keywords: Amman Stock Exchange, Stock prices, Dividends, Assets Returns, Net cash flows from operations, Service companies

\section{Introduction}

The necessity for additional financial capitals required for building strong economies caused the search for financial funding from a variety of banks sources. This has highlighted the importance of security markets as they have an important source in providing liquidity by shifting financial resources from surplus units to deficit units to increase productivity and channel available resources to the most profitable areas and to realize economic performance. Also, financial markets give many advantages to the national GDP as it is part of their responsibility in business financing and provide liquidity for new investments. It is worth to add that the availability of financial instruments will contribute to economic growth rates (Al Shabib al-Jubouri, 2005).

Due to the importance of the stock market role in Jordan's economy, the Amman Stock Exchange (ASE) was established in 1978 to play dual roles: first as the capital market supervision, and second as the stock exchange. Among its main objectives is the development of national wealth via the investment in securities, and to regulate and control the issuance process of securities in safety, ease, and speed of dealing with investors (JSC, 2016).Since equity shares are the most important financial securities traded in the stock market, and due to the many factors related to their profitability and performance, it was deeming necessary to take into consideration the impact of some factors represented in (dividends, assets return, and net cash flows from operations).This study concentrates on the market value of service companies share prices listed on ASE, with the aim of improving the shares market value and improving their comparability with other financial sectors in a way that ensures their survival and sustainability.

\section{Study Parameters}

\subsection{Study Problem}

Shares prices in the stock market are characterized by wide fluctuations, which requires the provision of confidence and credibility in the stock market to maintain the stakeholders rights in general, and in particular 
current and prospective investors, by setting an appropriate model to explain these fluctuations in a scientific and appropriate manner, so fluctuation and difference in share prices The service-sharing companies need to question the causes of this fluctuation. Therefore, the study problems formulated to answer the following main question:

Is there an effect of the following financial indicators (dividends, assets return and net cash flows from operations) on shares market value of the services companies listed on ASE.

\subsection{Research Importance}

The importance of this research stems from the importance of the shareholding companies' shares market value and their significant effect on the investment process. The share value is affected by financial and non-financial factors. This study will present a set of financial factors such as dividends effect on the shares market value, which contributes to the linkage between these factors with the market value of stocks, to screen out the positive effects and their role to achieve greater attraction local as well as external investors; and will help in the process of taking appropriate decisions in accepting or abandon investment. The services sector is an important sector of the Jordanian economy; its share value is about $24 \%$ of ASE.

\subsection{Study Objectives}

To examine the effect of certain financial indicators such as (dividends, asset returns and net cash flows from operations) on the market value of service companies shares listed on the ASE. These objectives are as follows:

1. Determine the dividends distributed effect on the market value of service companies shares listed on ASE.

2. Determine the return on assets effect on the market value of service companies shares listedon ASE.

3. Determine the cash flows from operating operations effect on the market value of service companies shares listed on ASE.

\subsection{Study Model}

The study model was based on the collection and content of previous studies and is formulated as follows:

\begin{tabular}{ll}
\hline Independent Variables & Dependent Variable \\
\hline 1. Dividends. & Stocks Market Value \\
2. Return on assets & Stocks Market Value \\
3. Net cash profits from operations & Stocks Market Value
\end{tabular}

\subsection{Study Hypotheses}

$\mathbf{H O}_{1}$ : There is insignificant impact at $(\mathrm{P} \leq 0.05)$ of distributed profits on the market value of service companies shares listed on ASE.

$\mathbf{H O}_{2:}$ There is no statistically significant effect at $(\mathrm{P} \leq 0.05)$ of assets returns on the market value of service companies shares listed on ASE.

$\mathbf{H O}_{3}$ : There is no statistically significant effect at $(\mathrm{P} \leq 0.05)$ of the net cash flows from operating operations on the market value of shares of service companies listed on ASE.

\section{Theoretical Framework}

Studies and literature in financial accounting and economics concerning the factors influencing the shares prices, as these factors have an aggravated effect on profits and rely on the companies contributing decisions. In case of shares falling prices this leads to losses, and if prices rise, these factors have been studied in an opposite way and have been studied separately. The public shares are usually priced on the principle of marginal pricing. Supply and demand forces represent the end result of securities pricing and the highest influential factor affecting the shares in the stock market (Mutawa, 2007).

Among the highest effective factors that affect the shares by investors are:

- The announcement of the introduction of new products

- The integration and changes in government policy affecting the interest rates and financial statements of companies

- Advertising dividends

- The stock prices 
These factors are reflected in the future prosperity of the market. Investments are the result of the downward trend in stock prices, and the growing trend of stock prices is leading to the development and recovery of the financial market (Rose, 2003).

The daily stocks fluctuation causes investors to doubt the efficiency of the market. Stocks price changes usually reflect new information. Shares prices are heavily influenced by information received from home establishment. Good news causes stock prices to rise and, conversely bad news will cause stock prices to fall (Malhotra, 2009). Stocks are usually affected by many factors, such as the financial statements, specifically the balance sheet. The balance sheet usually presents the financial position of the entity which affects the financial position of the corporation. Direct and indirect accounting plays a basic role in determining the share price. On the bases of prosperities of life is the extent of the stability of the economic and political situation, this factor has an influential effect on the stock prices determination (Selvon, 2008).

\subsection{Stocks}

The shares are the basic component of the company's capital and are the most vital types of securities traded in the financial markets and constitute a right of ownership.

The shares are issued through a certain shareholding company with a standard value per share. The shares are classified into:

\section{A. Common Shares}

These constitute the largest shares traded in the secondary stock market and they grant their holders several basic rights such as:

1- The right to elect the Board of Directors of the Company.

2- The right to attend the General Assembly and vote on the decisions.

3 - The right to receive the annual profits achieved by the company.

4- The right to sell the stocks through the financial market.

5- The right to receive a share of the net assets of the company in case of company liquidation.

\section{B. Preferred Shares}

Preferred shareholders have priority to receive their shared profits and the ability of converting their preferred shares into ordinary shares. The holders of these shares are entitled to an agreed dividend rate. Also, they have the right to receive their rights from the company's property in the event of liquidation but they do not have the right to vote (Kieso et al., 2013).

\subsection{Dividends}

The distribution of profits is a very important financial decision for the corporation, as it puts the company in a comparison between two positions, the first is the pay out of a certain part of the profits to the common shareholders; and holding retained earnings which are a part of the profits to the company's need to invest and benefit from those funds for as long as possible. The distributed rate of profits has an effect on the value of the company stocks.

The company's ability to distribute dividends on the company's share market value as is reflected in the profit distribution policy as evidence of the success and efficiency of the company's performance. The increase in dividend distribution leaves the positive impression of equity holders and dealers in the stock market (Gitman \& Zutter, 2012).

The dividends policies are diversified, some of which follow the policy of distributions based on:--retained earnings policy

- Policy of non-distribution of dividends in the short period;

- The policy of distributing a lot equals the share's market value;

- The policy to distribute of a certain percent of profits (apparent, 2006).

The fresh and small companies adopt the precautionary policy, which incorporates that they hold as much profit as possible to finance their own projects. (El-Henawi \& Al-Abd, 2002).

The dividends' policy is among the influential factors that affect the market value of the shares. (Khalaf, 2006). 


\subsection{Assets Return}

Measuring the assets return is an indicator for investors to estimate the profitability of the company through capital and equity credits, which indicates the company's overall profitability.

It also provides an evidence of the company's ability to achieve profits via its investments, as well as measuring the company's efficiency in using the resources available to it.

Incremental profitability reflects the company's ability to exploit its assets to generate profits which is measured by dividing the net profit after tax on total assets (Zubaidi, 2011).

The return on assets ratio is an important criterion for measuring the company's assets and the tax burden.

The return on assets ratio is expected to address the following objectives:

1- Comparison between the return's rate and the borrowing cost, which enables the company to take its decisions about borrowing.

2- Comparison between the performance of various companies and their operational capacity and efficiency. (Al-Nu'mi et al., 2014; Al-Zubaidi, 2011).

\section{Previous Studies}

1. Al Masri Study(2011): The study intended to analyze the price behavior of the companies listed on the Palestine Securities Exchange in a bid to discover the efficiency of this market. Accordingly, the stocks' closing prices were collected weeklyfor the period 2006-2009.

Many tests were used to measure the independence rate and the efficiency of the stock exchange. Pearson test was used to measure how the five market sectors were correlated. ARIMA test, showed the direction of the prices closing movement and the ability to forecast the future prices. Test outcomes showed that Palestine Securities Exchange is not at an efficiency level to forecast the stock closing prices. The study recommended the need for more professional information to achieve continuous transparency and objectivity level.

2. Arabsalhi and Mahmoodi (2011): This study intends to investigate if the value based measures are better than the balance sheet data in explaining stock returns. A pooling of 115 Iranian companies listed in the Tehran Stock Exchange (TSE) for the period $(2001-2008)$ was used to investigate the ability of four value-based measure: Economic Value Added(EVA).

Refined Economic Value Added (REVA), Market Value Added(MVA), Shareholders Value Added(SVA), were compared with the five accounting-based measures (including Earning Per Share, Return On Equity, Return On Assets, Cash Flow from Operations and Return On Sales) in explaining stock returns. Study results did not give evidence which support assertions that value-based measures are more practical than the traditional accounting measures. Relative information content tests showed that stock returns are linked with ROA and ROE more than other performance measures.

3. Ramadani Research (2012): The research aimed to realize the impact of dividends policy on the value of Jordan's ASE prices, study sample consisted of 30 companies listed on (ASE), for three sectors: financial, service and industrial sectors, for 2008 - 2010 period to study the effect of the dividend policy and the distribution of profits through the profit indices per share through using simple linear and multiple regression tests. The study revealed that the impact of the profit distribution policy on the institutions' shares values are highly significant and thus have a positive effect on their shares values.

4. Abdul Jalil Study (2012): Researcher examined the extent at which investors in Jordan's (ASE) value the securities for the effectiveness of operational cash flows in a collective and individual manner. The study sample consisted of (23) Jordanian public share holding companies listed on ASE for the period between 2001 -2010. Study results indicated that there is no positive relation between operational cash flows and the prices of concerned shares.

5. Kabajeh et al. Study, (2012): This Research intended to test the linkage between the following ratios: (return on assets, return on equity and return on investment), individually and collectively, on the shares market value of Jordanian public shareholding companies for 2002-2007 period. The methods of study used were: linear regression methods which aimed to test the relation between the study variables. Study outcomes showed a significant relation between the ratios: return on assets, return on equity, and the return on investment, on the shares market values; However, test results revealed that there was a low positive relation between: both the return on assets and return on investment on the shares market value separately. Moreover, study has shown that there was no relation between return on equity and the market value of shares. 
7. Taleb Study (2013): The study aimed to evaluate the Syrian banking sector financial quality in a bid to illustrate the relationship between the financial indicators used to evaluate the banks financial adequacy and stock market prices, aiming to arrive to a quantitative model that explains the effect of financial indicators on the price common share for the period 2008-2012, in a bid to assist investors in how to invest in Damascus Stock Exchange. Multiple linear regression test was the best valid test to predict which of these banks can be added together to the financial statements prepared for the publication of financial reports. Consequently, It managed to prepare a quantitative model for forecasting the set of stock prices of listed banks on Damascus Stock Exchange. The formula was mainly based on the value-added market to the banks. Upgrading the Syrian banking system and the Damascus Stock Exchange in order to stimulate their role more efficiently in the Syrian economy.

8. Chavali and Nusratunnisa Study (2013): study aimed to confirm the impact of distributed dividends on the Indian companies stocks prices. The sample size (67) companies announced dividend distributions for $2007-$ 2011 period, the study aimed to measure the effect and ability of distributed profits on the shares prices. Study procedure was to compare shares prices in about 20 days ahead to the dividends distribution date and twenty days after; and reaching the conclusion that market share prices are mainly affected via advertising of profits distribution dates which reflected that the shares market value have grown up in general prior to the profits payment date.

9. Yang and Wu Study (2015): This study intends to inquire the effect of declaring cash dividends before and after the losing the right to receive such profits. The study sample included the companies listed on Taiwan stock market and was conducted for the period 2001 - 2012, using a method to discover the event for this end, in order to reach a clear rise in the share price during the ten days preceding the date of loss of the right to receive distributions of profits, representing a period more than the ten-day period following the date of loss of right In the distribution of such profits.

\section{What distinguishes this study from previous ones:}

It is well known that there were many studies that dealt with this subject. However, this study differs from the past studies as this study is to link a group of financial indicators and factors and test their impact on the services stocks market value.

\section{Methodology of the Study}

This study is used the annual financial reports of service companies listed on the ASE for 2011- 2015 period, the researchers used the descriptive analytical methods to study the financial statements.

\subsection{Society and Study Sample}

The study society is the set of 54 service companies listed on ASE at 2016-year end. To select a study sample, the researchers selected (27) companies, and the sample companies were selected in random stratified manner for (2011-2015) period.

\subsection{Data References}

Study data was collected from the following sources:

1) Primary Sources: The financial statements of the public shareholding companies listed on the ASE during the period 2010-2015.

2) Secondary sources: The researchers retrieved required information from local and foreign references: books, periodicals, articles, researches, websites, and daily publications issued by the ASE.

\subsection{Analysis Methods}

For the purposes of achieving the study outcomes, following analytical procedures were used:

1) Statistical descriptive methods: where the descriptively analysis used the study the data variables in order to extract several descriptive statistical measures.

2) To test the study hypotheses: multiple regression model was used in order to test the impact of the independent variables on the dependent variables, also validity testing methods such as normal distribution, self-correlation, linear interference, and (SPSS) were used.

\section{Statistical Analysis}

Data was analyzed out to stimulate the study results for the service companies listed on ASE. The analysis is made up of three axes:

--The first axis is the descriptive elaboration of study variables via using a number of descriptive statistical 
measures: arithmetic mean, the maximum value, and the lowest value.

-- The second axis is to verify the workability of the data for statistical analysis and to verify the limit at which the data is normally distributed, the linear interference test, and the self-correlation test.

-- The third is the hypotheses testing by calculating the multiple regression coefficients of the form and discuss the results by the SPSS test V (22) statistical package.

\subsection{The Descriptive Statistics of the Study and Its Variables}

Table 1. Results of study descriptive test

\begin{tabular}{lllll}
\hline Variables & Maximum & Minimum & Std. Deviation & Mean \\
\hline Distributed Profits & 15400000 & 0 & 3208019 & 1963799 \\
Return on Assets & 31.45 & -23.57 & 7.81 & 5.60 \\
Operating Net Cash Flow & 38798500 & -11221236 & 6354086 & 3700013 \\
Shares Market Value & 16.44 & 0.08 & 2.54 & 2.24 \\
\hline
\end{tabular}

Table 1 presents the outcomes of the descriptive test of the independent variables and the dependent variable represented by the market value of shares. The average market value of shares and the average distributed dividends values indicates that dividends in the sample companies were good. Also, the return on assets of the sample companies indicates the ability of these companies to achieve adequate returns to their assets through their profits. It is worth to note that the arithmetic mean of the net cash flows from operating activities has reached (JD 3700013) which reflects a positive cash flow for the study sample.

\subsection{Normal Distribution Test}

The normal distribution of the study variables was performed using the Kolmogorov-Smirnov test to determine the normal distribution of the study variables as follows:

Table 2. Test results of the normal distribution of the study variables

\begin{tabular}{|c|c|c|c|c|}
\hline \multirow[t]{2}{*}{ No } & \multirow[t]{2}{*}{ Variable } & \multicolumn{2}{|c|}{ Kolmogorov-Smirnov } & \multirow{2}{*}{ No. } \\
\hline & & P-Value & $\mathrm{K}-\mathrm{S}$ & \\
\hline 1 & Shares Market Value (Dependent Variable & 0.053 & 0.200 & 1 \\
\hline 2 & Dividends (Independent Variable) & 0.051 & 0.270 & 2 \\
\hline 3 & Return on Assets (Independent Variable) & 0.079 & 0.081 & 3 \\
\hline 4 & Net Operating Cash Flow (Independent Variable) & 0.096 & 0.183 & 4 \\
\hline
\end{tabular}

Table 2 shows the results of the elaboration of the normal-distribution data using the Kolmogorov-Smirnov test. The table also presents the test outcomes of data approximation from the natural distribution related to continuous variables.

In view of Table 2, it is evident that all the variables of the study follow the normal distribution. Therefore, we can use the relevant tests of the data related to the effect of financial indicators on the market value of shares in companies operating in the services sector listed on ASE.

\subsection{Linear Interference Test and Self-Correlation Test}

The second step of the validation test is the linear interference test and the self-correlation test of the study variables. The outcomes are presented as follows: 
Table 3. Linear interference test and self-correlation test

\begin{tabular}{|c|c|c|c|}
\hline & \multirow{4}{*}{ Variable } & \multirow{2}{*}{\multicolumn{2}{|c|}{ اختبار التداخل الخطي }} \\
\hline & & & \\
\hline & & \multicolumn{2}{|c|}{ Multicollinearity } \\
\hline & & VIF & Tolerance \\
\hline & Return on Assets (Independent variable & 1.553 & 0.644 \\
\hline & Net Operating Cashflow (Independent variable) & 1.270 & 0.306 \\
\hline
\end{tabular}

Table 3 presents the Multicollinearity Test: Collinearity Diagnostics is calculated by the Tolerance coefficient for every independent variable and then finding the Variance Inferential Factor (VIF) parameter. It is noted from the table that the VIF coefficient for each of the variables did not exceed (5), which shows that there is no linear interference problem in the study model. Autocorrelation Test is conducted to ensure that there is no problem of self-correlation in the model, this was tested by Durbin-Watson test, where the problem arises when the contiguous amounts of the factors are interrelated, thus affecting the validity of the model. The value of this test ranges between (0-4) which indicates that at 0 level there is a strong positive correlation, and at levels close to (4) reflect a strong passive correlation, and the optimal result is between (1.5-2.5) indicating that there is no intrinsic correlation between the adjacent values of the variables (Qasem et al., 2016). Table 3 also indicates that the calculated D-W figure of the research model was (2.057), since this value falls within the appropriate range, it is clear that there is no problem of self-correlation that affects the validity of the model.

\subsection{Pearson Correlation Matrix for Study Variables}

The researcher relied on Pearson's correlation matrix to find the correlation between all study variables as follows:

Table 4. Pearson correlation matrix results for the study variables

\begin{tabular}{lllll}
\hline Variable & $\mathrm{Y}$ & $\mathrm{X} 1$ & $\mathrm{X} 2$ & $\mathrm{X} 3$ \\
\hline $\mathrm{Y}$ & 1 & & & \\
$\mathrm{X} 1$ & $0.579^{* *}$ & 1 & & \\
$\mathrm{X} 2$ & $0.724^{* *}$ & $0.592^{* *}$ & 1 & \\
$\mathrm{X} 3$ & $0.393^{* *}$ & $0.832^{* *}$ & $0.451^{* *}$ & 1 \\
\hline
\end{tabular}

**.Correlation is significant at the 0.01 level (2-tailed).

*. Correlation is significant at the 0.05 level (2-tailed).

Where:

-Y shows the market value of stocks as a dependent variable,

-X1 refers to distributed profits as a figure reflected by the size of dividends logarithm distributed as an independent variable,

-X2 refers to the ROE as an independent variable,

-X3 refers to net cash flows from operations as an independent variable.

Table (4) reflects the relation between the study variables in the service companies listed on ASE. By checking the table figures, there is a strong relation between the study's primary variables and the dependent ones. The maximum correlation between the return on assets and the market value of equities was (0.724) indicating a positive correlation between each of them, while the value of the computed correlation between the distributed dividends as measured by the natural logarithm test was $(0.579)$, which represented a positive relationship between each of them.

It is important to note the existence of other relationships between the independent factors as the most high correlation between the distributed profits as was computed by the natural logarithm test of the size of the profits and the true operational cash flows amounted to (0.832) which represent a positive relationship between them. Followed by the distributed profits as measured by the natural logarithm of the volume of dividends and return on assets amounted to (0.592) which represents a positive relationship as well. 


\subsection{Hypotheses Test}

The study hypotheses showed that there is no statistical impact on the total financial factors (dividends, return on assets and net cash flows from operations) combined in the market value of shares of the services sector companies listed on ASE

To determine the explanatory ability of the formula as a whole, the multiple regression test (Fisher's distribution $-F)$ was used, where:

-Calculated value of F must be higher than its tabular value at a confidence level (0.95) to accept the model.

-Calculated $\mathrm{T}$ value had determined the effect of the independent variables on the dependent variable. The absolute value of the calculated $\mathrm{T}$ must be higher than its tabular value at the (Sig $<0.05)$ level .

R Square (adjusted) is measured to show how accurately the independent variables of the dependent variable are interpreted.

Table 5. Multiple regression test results for all financial factors in the market value of shares

\begin{tabular}{lllll}
\hline Model & B & Coefficients & T & Sig \\
\hline Constant & 0.863 & --- & 4.707 & 0.000 \\
X1 & 0.418 & 0.402 & 3.506 & 0.001 \\
X2 & 0.588 & 0.577 & 8.082 & 0.000 \\
X3 & 0.160 & 0.202 & 2.950 & 0.043 \\
F test Model $=57.910$ & Sig F= 0.000 \\
Adjusted R Square $=0.560$ & R $=0.755$ \\
F Distribution Table $=1.656$ & T Distribution Table $=3.889$ \\
\hline
\end{tabular}

Where:

-Y represents the market value of stocks as a dependent variable,

-X1 refers to distributed profits as- measured by using the distributed size of dividends logarithm as an independent variable,

$-\mathrm{X} 2$ refers to the ROE as an independent variable,

-X3 refers to net cash flows from operations as a separate variable.

Table 5 presents the outcomes of the multiple regression analysis of the independent variables (distributed according to the natural logarithm of the volume of dividends, the return on assets and the net cash flows from operations) combined and their effect on the variable. The computed value $\mathrm{F}=(57.910)$ which is higher than the tabular value (3.89) at (0.95) significance level indicates that this model is appropriate and has a high explanatory power. This result is also advocated by the significance factor $\mathrm{F}$ is $<(0.05)$ as its value is $(0.000)$. Thus, the zero (null) hypothesis has been rejected and the opposite hypothesis was accepted. This shows that there is a statistically significant effect on the total financial factors (dividends, return on assets, net cash flows from operations) on the market capitalization of companies in the services sector listed on the ASE.

It is important to indicate that the correlation coefficient $(\mathrm{R})$ which is $(0.755)$ confirms that there is a significant positive relationship between the financial factors included in the study sample represented by the study variables (dividends, return on assets, net cash flows from operations) and the market value of shares in service companies represented by the dependent variable (Y). Also, the value of the adjusted limiting factor (R2), which is about 0.561 , means that only $56.1 \%$ of the fluctuations in the market value of service companies shares can be explained by changes in the study variables represented by (dividends, return on assets, and net cash flows from operations).

The relative decline of the value of the coefficient of determination indicate that there are other factors that fall outside the scope of the mutual relationship between these two variables may have a mutual impact on each other.

\section{Hypotheses Test Results}

$\mathbf{H O}_{1}$ : The tests reflected that the value of Coefficient is $(0.402)$, which indicates a significant positive mutual relation between the dependent and independent variables, this means that the higher the distributed profits, the higher the market value of the shares. 
Also, study computations reflected the absolute value of calculated $\mathrm{T}$ amounted to (3.506), Which is above its tabular value (1.656) at (0.95) confidence level, this result confirms the value of $T$, as it was at $(0.001)$ which is less than (0.05) level.

As a result, null hypothesis is not accepted and is replaced by the opposite hypothesis,

$\mathbf{H O}_{2}$ : The test figures showed that the value of Coefficients is $(0.577)$, which reflects a strong positive correlation between the variables, this means that the higher the return on assets, is will cause an increase to the market value of the shares. Test also indicated that the absolute $T$ calculated was (8.082), which is higher than the tabular value (1.656) at a confidence level (0.95). This result confirms the value of the moral significance of $\mathrm{T}$ as (0.000), which was less than (0.05).

As per the decision rule, the zero (null) hypotheses were rejected and the alternative hypothesis was accepted.

$\mathbf{H O}_{3}$ : The test figures showed that the value of correlation Coefficients is 0.202 which reveals that a statistically positive relationship between the dependent and independent variables which means that the higher the cash flows from the operations, the higher the market value of the shares. The outcome of the study showed that the absolute value of calculated $\mathrm{T}$ (2.95) which is higher than their tabular value (1.656) at significance level (0.95). This result confirms the value of the significance of $T$, which was less than (0.05) at a value of $(0.043)$. In accordance with the decision rule that rejects the null hypothesis (HO) if the absolute value of the calculated $\mathrm{T}$ is higher than its tabular value at a significant value of Sig $\mathrm{T}$ less than 0.05 , the net cash flows from operating operations (X3) therefore causes an effect the market value of the shares $\mathrm{Y}$.

Accordingly, the third null hypothesis was rejected and the alternative hypothesis was accepted.

\subsection{Study Results}

As per the statistical tests and test hypotheses of the research, results are as follows: 1. 1-A significant effect of the financial indicators represented by (dividends distributed as per the natural logarithm of the dividends distributed, the return on assets and the net cash flows from operations) on the market capitalization of companies in the services sector listed on ASE.

2. There is a significant impact of dividends distributed on the market value of service companies shares listed on ASE.

The researcher refers the reason to be due to the accepted fundamentals in the stock markets; i.e. a large percentage of investors, believe that the more companies have profits, the more often the market value of stocks increase, as the demand for shares of these companies increases by investors.

This result was achieved by Chavali and Nusratunnisa research (2013), while the results differed with Ramdani research (2012).

3. There is a significant impact of the return on assets on the market value of service company shares listed on ASE. The researcher believes that the reason may be due to the nature of the sample companies, which are service companies whose buildings and equipment were financed through long-term liabilities and loans; Hence, the investors' views of the financial statements in the service sector are based on the return on assets as the pillar factor considered in their investment decisions, which reflects positively on the market value of their shares. However, this result was similarly achieved by Kabajeh et al. (2012).

4. There is a significant impact of net cash flows from operating operations on the market value of service companies shares listed on ASE, this may be due to the fact that the net operating cash flows affect the compulsory and optional provisions of companies. However, this result was different from Abdul Jalil study, (2012).

\subsection{Study Conclusions}

The study conclusions are as follows:

1-Financial analysts can use this study to forecast the future market prices of stocks and take their rational investment decisions, depending on scientific grounds when they make such decisions.

2-Companies need to disclose the appropriate information that stimulates the shares prices used by the investors in to take the right investment decisions.

3-Further studies were needed especially those that widens the view of the users who depend on the financial statements in determining the extent of their reliance on their investment and credit decisions on the published information. 


\section{Acknowledgments}

The researchers are grateful to our university, the Middle East University, Amman, Jordan, for the financial support granted to cover the publication fees of this research paper.

\section{References}

Abdul, J. T. (2012).The Impact of Net Operating Cash Flows on the Market Price of Jordanian Industrial Joint Stock Companies. Jordanian Journal of Business Administration, 8(4), 695-706.

AlAdham, M., Alaffo, A., Abukhadijeh, M. A., \& Qasem, M. F. (2016). Tax Evasion and Tax Awareness Evidence from Jordan. International Business Research, 9(12), 65-75.

Al-Nu'ami, A., Al-Saqi, S., Salam, O., \& Musa, S. (2014). Financial Management: Theory and Practice, Dar Al-Masirah Publishing, Distribution and Printing (5th ed.). Amman, Jordan.

Al-Saidi, I. (2011). Factors Affecting the Market Share Rate of Return", An Unpublished Master Thesis, Al-Azhar University, Egypt.

Al-Shabib, D., \& Jabouri, A. R. (2005) The importance of the development of the Securities Control Authority to raise the efficiency of the financial market, the Fourth Scientific Conference, Philadelphia University, Jordan.

Al-Zaher, M., \& Sameh, A. A. (2010). The Effect of Cash Flow Measurements on the Interpretation of Market Returns.

Al-Zahir, M. (2006). The Policy of Dividend Distribution and its Impact on the Stock Market Price (Applied Study on a Sample of Jordanian Commercial Banks listed on the Amman Stock Exchange). Bethlehem University Journal.

Al-Zubaidi, H. (2011). Fundamentals of Financial Management. Al-Warraq Foundation for Publishing and Distribution, Amman.

Arab Society of Certified Public Accountants. (2011). International Financial Reporting Standards", Abu-Ghazaleh Translation and Distribution, Amman-Jordan.

Arabsalhi, M., \& Mahmoodi, I. (2011). The Quest for the Superior Financial Performance Measures. International Journal of Economic and Finance, 4(2), 116-125.

Berenson, R., \& Levine, Y. (1988). On the evaluation of structural equation models. Journal of the academy of marketing science, 16, 74-94. http://dx.doi.org/10.1007/BF02723327.

Chavali, K., \& Nusratunnisa. K. (2013). Impact of dividends on Share Price Performance of Companies in Indian Context. SDMIMD Journal of management, 4(1), 4-9.

El-Henawy, M., \& El-Abed, G. (2002). Financial Administration, Dar Al-Jamaa'ia, Alexandria.

Francic, J. S., \& Vincent, L. (2003). The Relative and Incremental Explanatory Power of Warnings and Alternative Performance Measure for Returns. Contemporary Accounting Research, 20(1), 121-164.

Gitman, L., \& Zutter, C. (2012). Principles of Managerial Finance (13th ed.). USA: Prentice Hall.

Haddad, F. (2014). Financial Management (4th ed.). Darhamdhalan Distribution and Distribution, Amman, Jordan.

Hammad, T. (2003). Accounting Standards Encyclopedia: Explanation of International Accounting Standards and Comparison with American, British and Arab Standards. University House, Alexandria.

Hayduk, L. (1987). Structural equation modeling with LISREL. Johns Hopkings University Press.

Kabajeh, A., Al Nu'aimat, M., \& Dahmash, N. (2012). The Relationship between the ROA, ROE and ROI Ratios with Jordanian Insurance Public Companies Market Share Prices. International Journal of Humanities and Social Science, 2(11), 115-120.

Kakumula, H. (2003). Investments and Financial Markets, Dar Al-Safa Publishing and Distribution (1st ed.).

Khalaf, F. (2006). Capital Markets. The World of Books for Distribution, Irbid, Jordan.

Kieso, D., Weygandt, J., \& Warfield, T. (2013). Intermediate Accounting (14th ed.).

Malhotra, A. (2009). Select the Right Strategy For Stock Trading. Retrieved from http://ezinearticles.com/?Select-the-Right-Strategy-For-StockTrading\&id=2754386 
Masry, M. (2011). Analysis of the behavior of stock prices and its impact on the efficiency of the Palestine Securities Exchange (analytical study). Islamic University in Gaza.

Mutawea, S. A. H. (2007). Department of Financial Markets and Institutions, Mansoura University, Egypt.

Newton, H. (2014). Common Stock" EBSCO Research starters.

Qasem, M. F., Abukhadijeh, M. A., \& AlAdham, M. A. (2016). Customer Relationship Management and Customer Retention in Jordanian Bank. International Business Research, (9). http://dx.doi.org/10.5539/ibr.v9n9p41

Ramdani, H. (2012). The Effect of the Profit Distribution Policy on the Value of the Institution Capitalized in the Financial Market. A Sample Study of Institutions Traded in the Amman Financial Market during the Period from 2008-2010.

Rose, P. S. (2003). Money and Capital Markets (8th ed.). McGraw Hill.

Schroeder, R., Clark, M., \& Cathey, J. (2011). Financial Accounting Theory and Analysis Text and Cases (10TH ed.).

Selvon, M. (2008). How Liabilities Assets Ratio Determines Financial Status. Retrieved from http://ezinearticles.com/?How-Liabilities-Assets-Ratio-Determines-Financial-Status\&id=1261935

Taleb, B. (2013). Evaluation of the Financial Performance of Banks and its Impact on Stock Prices: A Study in the Damascus Securities Market.

Yang, J., \& Wu, T. (2015). Announcement Effect of Cash Dividend Changes around Ex-Dividend Days: Evidence from Taiwan. International Journal of Business and Finance Research, 9(2), 77-91.

Zerari, A. N., \& Farah, G. (2001). Financial Markets, Dar Wael Publishing and Distribution, Amman.

\section{Copyrights}

Copyright for this article is retained by the author(s), with first publication rights granted to the journal.

This is an open-access article distributed under the terms and conditions of the Creative Commons Attribution license (http://creativecommons.org/licenses/by/4.0/). 